\title{
Transfer at the level of argument structure or morphology: a comparative study of English and Persian unaccusative and unergative verbs
}

\author{
Farzaneh Dehghan \\ Farhangian University, Shiraz, Iran \\ Reza Rezvani \\ Yasouj University, Iran
}

\begin{abstract}
Transitivity alternation refers to the causative/inchoative alternation of some unaccusative verbs. Different languages use different patterns to show transitivity alternation morphologically. While some languages like English use zero or no overt lexical marking, other languages (e.g. Spanish, Turkish, and Japanese) use overt morphological markers to show transitivity. This study aims to investigate the degree to which similarities and/or mismatches between English and Persian influence the use of unaccusative and unergative verbs by Persianspeaking learners of English. Based on different verb types in English and Persian, seven verb categories were identified as the basis for comparison. A forced-choice elicitation test including 48 items was developed based on these seven verb categories. A proficiency test was also used to divide participants (116 undergraduate students of English) into high and low proficiency groups. The results revealed findings more in line with transfer at the morphological rather than the argument structure level (Montrul, 2000). Alternating unaccusatives with similar equivalent structures for transitive/intransitive pairs in Persian and non-alternating unaccusatives with different structures for transitive/intransitive pairs in Persian seem to be the most difficult verb categories for learners. The effect of proficiency level was also significant on the recognition of correct structures.
\end{abstract}

\section{Keywords}

comparative study, unaccusative verbs, unergative verbs, transitivity alternation, argument structure level

\section{Introduction}

Different languages do not have similar patterns regarding the type and number of argument structures that they attribute to verbs (Pinker, 1989). Accordingly, transitivity alternation, which refers to the causative/inchoative alternation of some unaccusative verbs, has been the focus of many studies (Montrul, 1999; 2000; 2004; Cabrera and Zubizarreta, 2005b; Cabrera, 2010). While changing the word order and eliminating the agent NP in inchoative forms seem to be universal features, languages differ in the way they exhibit this alternation morphologically. English, for example, uses zero or no overt lexical marking, while many other languages (e.g. Spanish, Turkish, and Japanese) use overt morphological markers to show transitivity (Montrul, 2000). As a result, when learners from different linguistic backgrounds try to learn a language with a different argument structure system, the effect of L1 transfer on the initial state and later development of the interlanguage system becomes important. The initial state, in general, can be defined as the "underlying knowledge about language structures and principles 
that is in learners' heads at the very start of L1 or L2 acquisition" (Saville-Troike, 2005, p. 16). In L2 acquisition, the initial state includes "the kind of unconscious linguistic knowledge that the L2 learner starts out with in advance of the L2 input and/or to refer to characteristics of the earliest grammar" (White, 2003, p. 58). In other words, the initial state contains everything that the L2 learner brings to the very beginning stages of the $\mathrm{L} 2$ acquisition process.

Many theories have been proposed to identify the manner and sources of initial state knowledge in L2 acquisition. Two important theories are the Full Access Model (Epstein, Flynn and Martohardjono, 1996) and Full Transfer/Full Access Hypothesis (hereafter FT/FA; Schwartz and Sprouse, 1996). The first model proposes that the initial state of L2 acquisition is Universal Grammar (UG) while Full Transfer Hypothesis maintains that "the initial state of L2 acquisition is the full computational system of the L1 grammar" (Montrul, 2001 a, p. 159), though interactions with UG may also occur. According to FT/FA, L2 learners at the beginning stages of L2 acquisition produce utterances which are more in line with the marked member of the pair if their first language uses different morphological markers to show transitivity (White, 2003). For example, Spanish and Turkish are two languages which use overt morphology to show transitivity alternation for some verbs. Spanish learners of Turkish and Turkish learners of Spanish accurately reject verbs which do not have overt inchoative morphemes and accept those which have an overt morpheme. On the other hand, in the case of L1 English learners (a language with zero morphology in showing transitivity) who are learning these two languages as their $L 2$, it has been observed that forms similar to the passive morpheme are accepted to some extent while other incorrect forms lacking the necessary inchoative morphemes are rejected (Montrul, 2000; 2001 a, b).

In addition, beginner learners overgeneralize causatives the way children learning their first language overgeneralize, i.e. they incorrectly accept or produce lexical causatives with nonalternating unaccusatives. Montrul (1999; 2001a) argues that transfer is not the source of overgeneralized causatives because these structures are not acceptable in the learners' $L 1$. She suggests that these errors are caused by the fact that L2 learners have not acquired the L2 lexicosemantic features which are important in determining which verb class can alternate in transitivity. As Cabrera and Zubizarreta (2005a, p. 15) state, "given their incomplete L2 knowledge, learners resort to a default transitive lexico-semantic template (NP CAUSE NP BECOME verb) that they use irrespective of verb class". They conclude that L2 learners are sensitive to lexico-semantic verb properties that are relevant to the causative alternation in the L1. Therefore, lack of grammatical knowledge cannot fully explain responses. Cabrera and Zubizarreta (2003 cited in Cabrera and Zubizarreta, 2005b) suggest that these findings are compatible with an L1 transfer analysis, in which learners transfer the properties of alternating unaccusatives to non-alternating ones or use overpassivization instead (Balcom, 1997; Ju, 2000; Kondo, 2003; 2005; Ghafar-Samar, Shabani and Karimialvar, 2011). The point is that according to Montrul (2000; 2001b), Full Transfer/Full Access holds at the level of morphology in this transfer process.

This difference in the levels of transfer (argument structure or morphology) constitutes the basis of Montrul's (2000) proposal for a "modular view" of transfer. Transfer at the level of argument structure and transfer at the level of morphology are in opposition and as a result of each, different possibilities can be derived. If transfer occurs at the level of argument structure, then L2 learners must not have any problem in acquiring equivalent structures. If transfer occurs at the morphological level, on the other hand, morphological mismatches between $\mathrm{L} 1$ and L2 in terms of overt morphology (in spite of equivalent argument structures) will cause difficulties for L2 learners. In other words, the predictions are that "default linguistic mechanisms (from UG) play a role at the argument-structure level but that the L1 has a strong influence at the morphological level, particularly with the morphology of alternating verbs" (Montrul, 2000, p. 231). The modular view rejects the idea that the L1 computational system is transferred as a block. Rather it maintains that "transfer can be more advanced or pervasive in some domains than in others; that is, it can restructure or reconfigure earlier in some 
modules (perhaps syntax) but take longer in others (morphology or phonology)" (Montrul, 2000, p. 233).

Many studies have focused on the acquisition of unaccusatives and unergatives by L2 learners of different L1 backgrounds (Hirakawa, 1995; 2001 [L1 English, L2 Japanese]; Yuan, 1999 [L1 English, L2, Chinese]; Ju, 2000 [L1 Chinese, L2 English]; Montrul, 2000; 2001a [L1 \& L2 Spanish, Turkish, and English]; Inagaki, 2001; 2002, [L1 \& L2 English and Japanese]; Sorace and Shomura, 2001 [L1 English, L2 Japanese]; Cabrera and Zubizaretta, 2005a [L1 English, L2 Spanish]). These studies have utilized unidirectional or bidirectional designs as well as different instruments such as production tests, grammaticality judgment instruments, multiple-choice items and rating scales. The results of these experiments concur that English language learners whose first languages express alternations with overt morphology have difficulty in learning the transitivity alternations of English verbs.

Some of these studies have focused on the learnability problems unaccusative verbs cause for L2 learners (Zobl, 1989; Yip, 1990). In a series of experiments, Montrul (1999; 2000; 2001a \& b, 2004) examined the acquisition of argument structures by different $L 1$ and L2 learners. She found that if an L1 uses morphology to show this argument structure feature, learners are sensitized to these morphologies in the L2 (whether L2 uses similar, different or no morphology). She attributed this to transfer at the morphological level based on FTFA preliminaries. In other words, the presence or absence of certain L1 lexical features influences the L2 learners' interlanguage system of lexical entries. According to FTFA hypothesis, L1 is the basis of the L2 learners' interlanguage representation (including the argument structure and the argument changing morphologies. Later, in the presence of positive evidence, these representations and lexical entries are restructured based on Universal Grammar instantiations.

Persian is also a language which uses overt morphology for alternating in transitivity. This study aims to make a comparison between Persian and English structures and the way similarities and differences may cause problems for Iranian
EFL learners based on a Full Transfer Model of L2 acquisition. Accordingly, the study aims to answer these questions:

1) Regarding transitivity alternation, what verb categories exist in English in comparison with Persian?

2) Based on the unaccusative and unergative verb categories identified in question 1, to what extent do Persian learners of English transfer these verb categories into L2 English?

3 ) Is this transfer influenced by different levels of proficiency?

4) Are the results in support of transfer at the argument structure level or morphological level?

2. Distribution of unaccusative and unergative verbs in English and Persian Unaccusative verbs are those intransitive verbs that have only one argument, i.e. a theme rather than an agent (Burzio, 1986; Hagh-bin, 2003; Mansoori, 2005; Pinker, 1989; Zobl, 1989). In English, an alternation is possible regarding some of these verbs (in the examples provided, E stands for English and P stands for Persian):

E1) Sam broke the window. (Causative, transitive)

E2) The window broke. (Inchoative, intransitive)

Other examples of this category of verbs include:

E3) The wind opened the door.

E4) The door opened.

E5) The sun melted the ice.

E6) The ice melted.

E7) The storm sank the ship.

E8) The ship sank.

However, this is not the case with all unaccusative verbs. For example:

E9) The rabbit appeared.

E10) *The magician appeared the rabbit.

Unergative verbs are those verbs which are similar to unaccusative verbs in the sense that they also take one argument but that argument is an agent rather than a theme. These verbs do not have a causative alternation: 
E11) The child laughed.

E12) *Sam laughed the child.

The Persian language seems to have diverse patterns regarding these verb categories (Hagh-bin, 2003). However, no study has provided a comprehensive categorization regarding these verbs. The first type of verb consists of unaccusatives with transitive alternations. In the first group, which mostly consists of simple verbs, only a direct object-marker (DOM) $r a$ ? may be added to the theme in causative alternation:

P1) shishe shekast

P2) Sam shishe ra? shekast Window broke Sam window + DOM broke 'The window broke.'

'Sam broke the window.'

The first bracketed line shows the wordby-word English equivalent of the Persian sentence and the second one is the English sentence.

This can be contrasted with the passive The window was broken (shishe shekaste shod), which according to some views is different from an unaccusative verb. Other examples include pokhtan ('cook'), rikhtan ('spill') and shekarftan ('crack')

P3) ghaza? pokht

P4) Sam ghaza? ra? pokht meal cooked

Sam meal+DOM cooked

'The meal cooked.'

'Sam cooked the meal.'

P5) $a$ p b rikht

P6) Sam apb ra? rikht water spilled

Sam water+DOM spilled

'The water spilled.'

'Sam spilled the water.'

The verb shekaiftan ('crack') is of a different category in Persian. If it is used to mean sheka?ft (split or fracture), it has an alternation transitivity:

P7) zaminlarze zamin ra? sheka?ft

P8) zamin sheka?ft

Earthquake ground+DOM cracked ground cracked

'The earthquake cracked the earth.' 'The ground cracked.'
However, if it is used to mean tarak bardasht ('made sth crack'), it has only an intransitive form:

P9) Golda?n tarak barda?sht

Vase cracked

'The vase cracked.'

P10) *Sam golda?n ra? tarak barda?sht Sam bares shod goldarn tarak bokhorad

Sam made vase crack

'Sam made the vase crack.'

In other words, crack, which is an alternating unaccusative in English, has two equivalents in Persian; the first shekarftan is an alternating unaccusative while the second tarak barda?shtan is a nonalternating unaccusative in Persian. This is also the case with freeze which is an alternating unaccusative in English but has a Type-1 alternating unaccusative equivalent (yakh bastan) and a Type-2 alternating unaccusative equivalent in Persian (monjamed shodan/monjamed kardan). These verb categories will be explained below.

In the second category, which consists mostly of compound verbs (preverb + verb), the verbal element will also change as well as adding the object-marker element (DOM) rap:

\section{P11) dar bapz shod \\ P12) ba?d dar ra? bapz kard door opened wind door DOM open+CAUSE 'The door opened.' 'The wind opened the door.'}

It has been argued that this causative element (kard) is a light verb (Mansoori, 2005). It is interesting that in Persian, if you passivize the causative verbs of this category, you will have the same sentence as in unaccusative forms:

\section{P13) dar (bevasile bad) bapz shod door (by wind) open became 'The door was opened by the wind.'}

The third category of unaccusative verbs which do not have a causative or transitive alternation in English can be acceptable by adding a CAUS morpheme:

\section{P14) khargoosh zapher shod}


Rabbit appeared

'The rabbit appeared.'

P15) Shobadeba?z khargoosh ra?

zapher kard

Magician rabbit DOM

appear+CAUS

'The magician appeared the rabbit.

The unergative verbs in Persian exhibit an interesting difference compared with English. These verbs can have a causative counterpart but with a morphological change in the verb:

\section{P16) bache khandid}

P17) Sam bache ra? khanda?nd (khandarnid)

child laughed Sam child DOM

(laugh+CAUSE)

'The child laughed.'

'Sam made the child laugh.'
The verb khandid ('laughed') is a simple verb in Persian. The causative morpheme (a?nd=a?nid) in the causative counterpart khandand ('made laugh') which is also regarded by some scholars as a light verb (Mansoori, 2005) is a very productive causative morpheme in modern Persian. If you passivize this sentence, you will not have the first unergative sentence (as was the case with unaccusative verbs):

P18) bache (be vasile Sam) khanda?nde shod

child (by Sam) [laugh+CAUSE+past participle marker] became

Based on these English verb categories and their Persian equivalents a classification emerged which is presented in Table 1.

\begin{tabular}{|c|c|c|}
\hline & Verb c & examples \\
\hline 1 & $\begin{array}{l}\text { Alternating unaccusatives in English (Type } 1 \text { alternating } \\
\text { unaccusatives in Persian. Persian uses exactly the same } \\
\text { morpheme for both transitive and intransitive forms as in } \\
\text { English) }\end{array}$ & $\begin{array}{l}\text { break, cook, spill, crack, } \\
\text { rip }\end{array}$ \\
\hline 2 & $\begin{array}{l}\text { Alternating unaccusatives in English (Type } 2 \text { alternating } \\
\text { unaccusatives in Persian. Persian uses different morphemes } \\
\text { to show transitivity and intransitivity) }\end{array}$ & $\begin{array}{l}\text { sink, open, change, } \\
\text { wither, melt, continue }\end{array}$ \\
\hline 3 & $\begin{array}{l}\text { Transitives in English (Persian equivalence is Type-2 } \\
\text { alternating unaccusatives) }\end{array}$ & $\begin{array}{l}\text { damage, determine, } \\
\text { release, store, ruin, } \\
\text { abandon }\end{array}$ \\
\hline 4 & $\begin{array}{l}\text { Non-alternating unaccusatives in English (Type } 1 \text { non- } \\
\text { alternating unaccusatives in Persian. Persian uses different } \\
\text { morphemes to show transitivity and intransitivity) }\end{array}$ & $\begin{array}{l}\text { appear, disappear, } \\
\text { emerge, fall, rise, vanish }\end{array}$ \\
\hline 5 & $\begin{array}{l}\text { Non-alternating unaccusatives in English (Type } 2 \text { non- } \\
\text { alternating unaccusatives in Persian. Persian has a similar } \\
\text { structure) }\end{array}$ & $\begin{array}{l}\text { happen, occur, exist, } \\
\text { collapse, depart, sit, } \\
\text { stand }\end{array}$ \\
\hline 6 & $\begin{array}{l}\text { in English (Persian uses different morphemes } \\
\text { sitivity and intransitivity) }\end{array}$ & $\begin{array}{l}\text { laugh, cry, sleep, run, } \\
\text { dance, shine }\end{array}$ \\
\hline 7 & Unergatives in English (Persian has a sim & $\begin{array}{l}\text { swim, sing, stay, resign, } \\
\text { arrive, talk }\end{array}$ \\
\hline
\end{tabular}

\section{Table 1: Verb types}

These seven verb categories, which include both equivalents and mismatches between English and Persian, were used as the basis for comparison in this study.

\section{Method} Participants.

A total number of 116 undergraduate students (53 majoring in TEFL at Farhangian University in Shiraz and 63 majoring English literature at Shiraz University) took part in this study. They had studied English at the tertiary level between 2-4 years. They had had no natural exposure to English. Their age range was 21-23. 


\section{Instruments.}

Two instruments were utilized in this study. The first was the Oxford Placement Test at the intermediate level developed by Allan (1985). The test was used to divide students into high-intermediate and lowintermediate levels based on their levels of proficiency. The second instrument, which was a forced-choice elicitation task containing 48 items, was developed based on the seven categories of verbs obtained in the previous part ( 6 for each category). It should be noted that in the first category, the number of verbs found with the intended features in English and their equivalents in Persian were five and as a result, we had to have two different items for one of the verbs (break) to keep the number of items devoted to each category equal. Meanwhile, six items were added which included transitive verbs in both English and Persian, including find, read, build, plant, see, and need. These items were used as distracters.

The items were designed in a way to determine whether learners would transfer the Persian structures where there were mismatches between English and Persian. For example, the verb damage is a transitive verb in English but its Persian equivalent (apsib zadan; apsib didan) is a Type- 2 alternating unaccusative verb. The item provided a mini-cloze text to elicit the use of the verb as follows:

Last month, there was a strong earthquake in this area. Many houses (damaged/were damaged) in the earthquake and the tsunami that followed it.

On the other hand, the verb appear is a non-alternating unaccusative verb in English while its equivalent is a Type-2 alternating unaccusative verb in Persian (zapher shod/zapher kard):

There was a very big circus in our town last week. A magician was there who (appeared a rabbit/made a rabbit appear) out of a hat.

\section{Data collection and analysis.}

The two tests were administered in regular class time in one session. The students received instructions on how to complete the tasks. To analyse the data, at first the participants were divided into high and lowintermediate proficiency groups based on the mean of the proficiency test scores, which was 39 (out of 74). In order to obtain a more reliable classification procedure between the high and the low groups, the mid group was omitted from the data analysis process. Each of the low and high proficiency groups contained 40 participants. An independent t-test was conducted to find out whether this classification was significant or not. The tvalue was 23.19 , which was significant at $\mathrm{p}<.001$.

In the forced-choice elicitation task, the responses were scored in a way that each correct answer received one point and, as a result, each participant obtained a total score for the whole task. As the task was based on seven verb categories, a separate score was also calculated for each of these subcategories. As a result, because the number of items for each verb category was equal $(\mathrm{N}=6)$, a range of 0 to 6 points was possible for each verb category. The items were chosen in a way that each item has only one possible correct answer.

\section{Results and discussion}

Table 2 summarizes the mean scores obtained for the seven verb categories: 


\begin{tabular}{|l|l|l|}
\hline & Verb category & Mean \\
\hline 1 & Type-1 alternating unaccusatives in English and Persian & 2.39 \\
\hline 2 & $\begin{array}{l}\text { Type-2 alternating unaccusatives in English (Persian uses different } \\
\text { morphemes to show transitivity and intransitivity) }\end{array}$ & 2.54 \\
\hline 3 & $\begin{array}{l}\text { Transitives in English (Persian equivalent is Type-2 alternating } \\
\text { unaccusatives) }\end{array}$ & 5.12 \\
\hline 4 & $\begin{array}{l}\text { Type-1 non-alternating unaccusatives in English (Persian uses different } \\
\text { morphemes to show transitivity and intransitivity) }\end{array}$ & 1.23 \\
\hline 5 & $\begin{array}{l}\text { Type-2 non-alternating unaccusatives in English and Persian } \\
\text { Unergatives in English (Persian uses different morphemes to show } \\
\text { transitivity and intransitivity) }\end{array}$ & 3.83 \\
\hline 7 & Unergatives in English and Persian & 5.41 \\
\hline
\end{tabular}

\section{Table 2: Mean scores obtained from seven verb categories}

The results reveal interesting findings about the seven verb categories. The first group of verbs included alternating unaccusatives with identical transitive and intransitive forms in both English and Persian (break, spill, cook). Contrary to our expectations (because of the similarity of the argument structures in both languages), students made many mistakes and used the passive counterparts where the unaccusatives should have been used. In other words, though both English and Persian use a similar argument structure, this does not prevent Persian learners of English making errors in this verb category. This could be a piece of evidence against transfer at the level of argument structure and in favour of transfer at the level of morphology.

The second category of alternating unaccusatives consists of English verbs which have Persian equivalents with different morphological markers for transitive and intransitive pairs (wither, sink, open, ruin). For this category of verbs too, the mean obtained is relatively low. Overpassivization (68\%) was also common over inchoative structures (As a result of the sea storm last night, many boats sank/were sunk in the water near the sea shore). This overpassivization is compatible with Juffs's (1996) explanation, which proposes that L2 learners are looking for a structure with similar overt morphology in English as in their L1. The results of this category, which consists of equivalent argument structures but morphological mismatches between $\mathrm{L} 1$ and $L 2$, are also in favour of transfer at the morphological level.

The third category includes the verb damage which is a transitive verb in English but is an alternating unaccusative in
Persian (apsib zadan (T)/apsib didan (I)) with a morphological change. Though there are different argument structures in the two languages, participants had few errors in this category and accepted the passive rather than the ungrammatical unaccusative (The house was damaged/*The house damaged). It could be argued that the low degree of errors in this category can be attributed to the fact that for this category of verbs, the passive structure is acceptable, and as a result learners chose the correct structure. Again this result provides a piece of evidence against transfer at the argument structure level because, even though the argument structures are different in the two languages (and the expectation was that L2 learners make mistakes in this category), they performed well in this category.

Categories 4 and 5 are related to nonalternating verbs. Category 4 includes the verb appear, which is a non-alternating unaccusative in English but has intransitive/transitive counterparts in Persian with different morphologies (z?her shod/zapher kard). In other words, the mismatches are at both the argument structure and morphological level. It was the most difficult verb category for the participants. Most of the respondents (89\%) accepted the ungrammatical sentence *The magician appeared the rabbit rather than the grammatical sentence The magician made the rabbit appear. On the other hand, they did not make the same mistakes with the verbs in category 5 (happen, occur), which contains equivalent argument structures and morphology. As was mentioned earlier, the Persian counterparts of these verbs, as in English, do not have a transitive alternation. As expected, the structure make the earthquakes happen 
was selected significantly more frequently by participants than the ungrammatical sentence * happen the earthquakes. This was in contrast with the results of category 4 (appear) which has a transitive as well as an intransitive equivalent in Persian (of course with a morphological change in the light verbs shod $\rightarrow$ kard). In the case of category 4 , the participants preferred the ungrammatical structure to the grammatical sentence. The overuse of the structure MAKE STH VERB can be explained by the fact that this is a default structure which L2 learners of English turn to, which is also a marked structure in Persian acceptable for many verbs. However, in the case of appear the acceptability of the Persian structures may have misled learners into choosing the ungrammatical sentence *The magician appeared the rabbit. Overall, the results of these two categories also confirm Montrul's (2000) morphological transfer hypothesis. Meanwhile, in the case of intransitive sentences, participants accepted ungrammatical sentences such as *The accident was happened and *The rabbit was appeared, which is again a sign of overpassivization in places where unaccusatives are required.

Categories 6 and 7 consist of unergative verbs. Category 6 includes unergative verbs of English whose Persian counterparts have intransitive as well as transitive alternations with a morphological change (different argument structures and morphologies). Most of the participants were accurate in rejecting the ungrammatical sentences such as *He laughed the baby and correctly accepting the grammatical structure $\mathrm{He}$ made the baby laugh. This is the only case which is against the transfer at the morphological level hypothesis, which may be related to the particular nature of unergative verbs, which in contrast to unaccusative verbs, are easier to learn. Verbs of the last category (swim and sing), which have only intransitive forms both in English and Persian seem to be the easiest structure for these respondents, as is evident from the mean obtained. In this category we have equivalent argument structures and morphologies. Most respondents correctly rejected ungrammatical structures such as *He swam the child and accepted the grammatical sentences He made the child swim. The results of the last category are also in line with transfer at a morphological level. Overall, the results of this part confirm a modular approach of transfer.

These results are in agreement with previous research which confirms that L2 learners of English whose first languages use overt morphologies to show transitivity alternation fail to recognize the null morphology of English verbs (White et al, 1998; Montrul, 2000; Whong-Barr, 2005). The results are more in line with a modular view of transfer at the level of morphology. Based on the predictions of FT/FA, L2 learners should transfer L1 grammar in its entirety (including argument structure and morphological aspects) and, as a result, should not have made any errors. However, as the results showed, participants in this study made many different errors and this could be viewed as a piece of evidence in favour of the modular transfer view. Meanwhile, as was observed by the results of different verb categories in this study, the results are consistent with transfer at the morphological level view. Montrul (2000) has explained this fact by arguing that L1 influence at the level of morphology exists from the initial state while transfer at the level of argument structure is either nonexistent from the beginning or had finished for these learners.

It should be noted here that L1 transfer is just one factor which may influence the acquisition of a second language. Many personal, contextual and social factors have been proved to influence this process beyond the mere influence of second language learners' L1. Therefore, these results must not lead the readers to a narrow impression that L2 acquisition is only under the influence of $L 1$.

Regarding the question of proficiency level, the results of the independent samples t-test are summarized in Table 3: 


\begin{tabular}{|l|l|l|l|l|}
\hline Proficiency & Mean & SD & t-value & Sig. (two-tailed) \\
High-I & 31.12 & 2.29 & & \\
Low-I & 21.24 & 3.41 & 9.754 & .001 \\
& & & & \\
\hline
\end{tabular}

Table 3: Independent-samples t-test of high- and low-intermediate groups

As Table 3 illustrates, the means obtained between the groups is significant at $\mathrm{p}<.001$. In other words, the high proficiency group outperformed the low group comparing the overall score obtained for the elicitation task. In order to compare the performance of each group on the seven verb categories independentsample t-tests were utilized to see where the differences between high and low groups were significant. Table 4 summarizes the results:

\begin{tabular}{|c|c|c|c|c|c|}
\hline Proficiency & Mean & SD & Df & t-value & Sig. (two-tailed) \\
\hline $\begin{array}{l}\mathrm{H} \\
1 \\
\mathrm{~L}\end{array}$ & $\begin{array}{l}3.44 \\
1.34\end{array}$ & $\begin{array}{l}2.19 \\
.93\end{array}$ & $\begin{array}{l}39 \\
39\end{array}$ & 28.12 & .000 \\
\hline $\begin{array}{l}H \\
2 \\
L\end{array}$ & $\begin{array}{l}3.61 \\
1.52\end{array}$ & $\begin{array}{l}2.12 \\
1.3\end{array}$ & $\begin{array}{l}39 \\
39\end{array}$ & 22.437 & .000 \\
\hline $\begin{array}{l}\mathrm{H} \\
3 \\
\mathrm{~L}\end{array}$ & $\begin{array}{l}5.52 \\
3.16\end{array}$ & $\begin{array}{l}1.01 \\
.71\end{array}$ & $\begin{array}{l}39 \\
39\end{array}$ & 5.400 & .001 \\
\hline $\begin{array}{l}\mathrm{H} \\
4 \\
\mathrm{~L}\end{array}$ & $\begin{array}{l}1.84 \\
.72\end{array}$ & $\begin{array}{l}1.09 \\
1.23\end{array}$ & $\begin{array}{l}39 \\
39\end{array}$ & 3.349 & .001 \\
\hline $\begin{array}{l}\mathrm{H} \\
5 \\
\mathrm{~L}\end{array}$ & $\begin{array}{l}5.77 \\
2.52\end{array}$ & $\begin{array}{l}1.21 \\
.87\end{array}$ & $\begin{array}{l}39 \\
39\end{array}$ & 30.470 & .000 \\
\hline $\begin{array}{l}\mathrm{H} \\
6 \\
\mathrm{~L}\end{array}$ & $\begin{array}{l}4.78 \\
2.19\end{array}$ & $\begin{array}{l}1.13 \\
1.97\end{array}$ & $\begin{array}{l}39 \\
39\end{array}$ & 9.870 & .000 \\
\hline $\begin{array}{l}\mathrm{H} \\
7 \\
\mathrm{~L} \\
\end{array}$ & $\begin{array}{l}4.97 \\
2.24\end{array}$ & $\begin{array}{l}1.2 \\
.96\end{array}$ & $\begin{array}{l}39 \\
39\end{array}$ & 7.81 & .001 \\
\hline
\end{tabular}

Table 4: Results of t-tests for high and low groups for each verb category

The $P$ value was adjusted by the Bonferoni adjustment formula because of the multiple comparisons made. All the $t$ values are significant at the adjusted levels. This means that there is a significant difference between the performances of high and low proficiency groups in all seven categories of verbs. In other words, students make fewer errors regarding the use of these verbs as their proficiency level increases. As the results in Table 4 indicate, the high proficiency group has outperformed the low proficiency group in all the seven verb categories regardless of the similarities and/or differences between the argument structures of the verb categories. This is in line with the predictions of the FT/FA hypothesis, which predicts that when there are morphological mismatches between $\mathrm{L} 1$ and $\mathrm{L} 2$ in showing transitivity, beginner L2 learners tend to use the more marked members of the pairs (White, 2003).

As was stated earlier, beginner learners overgeneralize causatives similarly to children learning their Lls. Therefore, errors of accepting or producing lexical causatives with non-alternating unaccusatives can be attributed to either $\mathrm{L} 1$ transfer or overgeneralization in the L2 itself. According to Montrul (2001a), transfer (at the argument structure level) 
cannot be the source of overgeneralized causatives as these structures are not acceptable in the learners' $L 1$. She argues that these errors are due to the fact that L2 learners have not acquired the L2 lexicosemantic features which are important in determining which verb class can alternate in transitivity. In other words, they have not reached a threshold level of the lexicosemantic features of $L 2$ and may switch to the morphological features of their L1s.

According to the principles of the consciousness-raising approach to teaching formal aspects of language (Ellis, 2002), rather than presenting grammatical structures to language learners and forcing them to get involved in productive practice of those structures, their consciousness must be drawn to those structures. The results of such comparative studies could be helpful to materials designers who write language teaching books for L1 Persian learners of English. Those unaccusative and unergative structures around which learners are more likely to make mistakes can be highlighted and brought to the learners' conscious attention. This way, without forcing language learners to produce these structures and to practise them (which can be confusing and have no long-lasting effect), language learners' attention is drawn to the differences between English and Persian regarding these particular verb categories and the morphological mismatches that exist in showing transitivity alternation. Further research can show the effectiveness of such strategies in helping Persian learners of English learn these structures.

\section{Conclusion}

Research in the area of acquisition of argument structures in a second language has supported the thesis that L2 acquisition is strongly under the influence of the properties of learners' L1. Two competing theories exist regarding the domain of L1 influence on L2 acquisition, namely, the Full Access Model, wherein the initial state of $\mathrm{L} 2$ acquisition is UG, and the Full Transfer/Full Access Hypothesis according to which the initial state of $L 2$ acquisition is L1 grammar (Montrul, 2001a) with possible interactions with UG. FT/FA predicts that beginner L2 learners produce utterances more consistent with the marked member of the pair if in their L1 different morphological markers are used to show transitivity. The results of this study are more compatible with FT/FA hypothesis, as it was observed that low-proficiency students of English significantly used incorrect or less common grammatical structures regarding different intransitive and unergative verbs. On the other hand, L1 transfer can also occur at two levels: transfer at the argument structure level and transfer at the morphological level. If transfer occurs at the level of argument structure, then L2 learners should not have any problem in acquiring equivalent structures. Transfer at the level of morphology predicts that overt morphological mismatches between $\mathrm{L} 1$ and L2 will cause difficulties for L2 learners or that L1 plays a significant role at the morphological level even though the argument structures are equivalent. The results of this study revealed significant difficulties regarding the use of unaccusatives and unergatives in cases of both similarities and differences between English and Persian. However, these results are more in line with a transfer at the morphological level (Montrul, 2000) than a transfer at the argument structure level. Alternating unaccusatives (break, spill, cook) with similar equivalent structures for transitive/intransitive pairs in Persian and non-alternating unaccusatives (appear) with different structures for transitive/intransitive pairs in Persian seem to be the most difficult verb categories for Iranian EFL learners as was evident from the number of mistakes students made in these two categories. Regarding proficiency level, it had a significant effect on the degree of the errors students committed. This also provides another piece of evidence in favour of a morphological view of transfer in contrast to transfer as a block view.

\section{References}

ALLAN, D., 1985. Oxford Placement Test 1 B1. Oxford: Oxford University Press.

BALCOM, P., 1997. Why is this happened? Passive morphology and unaccusativity. Second Language Research, vol. 13, pp. 1-9.

BURZIO, L., 1986. Italian syntax: A government-binding approach. Dordrecht: Reidel. 
CABRERA, M. 2010. Intransitive/inchoative structures in L2 Spanish. In: C. Borgonovo et al., eds. Selected proceedings of the $12^{\text {th }}$ Hispanic Linguistics Symposium. Somerville, MA: Cascadilla Proceedings Project, pp. 160-170

CABRERA, M. and ZUBIZARRETA, M. L., 2005a. Overgeneralization and transfer in L2 Spanish and L2 English. In: D. Eddington, ed. Selected Proceedings of the 6th Conference on the Acquisition of Spanish and Portuguese as First and Second Languages. Somerville, MA: Cascadilla Proceedings Project, pp. 15-30.

CABRERA, M. and ZUBIZARRETA, M. L., 2005b. Are all L1 grammatical properties simultaneously transferred? Lexical causatives in L2 Spanish and L2 English. In: L. Dekydtspotter, ed. Proceedings of The 7th Generative Approaches to Second Language Acquisition Conference (GASLA 2004). MA: Cascadilla Proceedings Project, pp. 24-37.

ELLIS, R., 2002. Grammar teaching - practice or consciousness raising? In: J.C. Richards and W.A. Renandya, eds. Methodology in language teaching: An anthology of current practice. Cambridge: Cambridge University Press, pp. 167-174.

EPSTEIN, S., FLYNN, S. and MARTOHARDJONO, G., 1996. Second language acquisition: Theoretical and experimental issues in contemporary research. Behavioral and Brain Sciences, vol. 19, pp. 677-714.

GHAFAR-SAMAR, R. SHABANI, K. and KARIMIALVAR, N., 2011. Overpassivization of unaccusative verbs as a function of discourse pragmatics and verb type: Testing the fit in Persian. Iranian EFL Journal, vol. 7, no. 5, pp. 8-19.

HAGH-BIN, F., 2003. Barrasi sakhthaye namoteadi dar farsi (Examining the unaccusative structures in the Persian language). Faslnameh Elmi-Pajooheshi Ollome-Ensani Daneshgah Azzahra, vol. 43, no 13, pp. 61-95.

HIRAKAWA, M., 1995. L2 acquisition of English unaccusative constructions. In: D. MacLaughlin and S. McEwen, eds. Proceedings of the 19th Boston University Conference on Language Development. Somerville, MA: Cascadilla Press, pp. 291-302.

HIRAKAWA, M., 2001. L2 acquisition of Japanese unaccusative verbs. Studies in Second Language Acquisition, vol. 23, pp. 221-245.

INAGAKI, S., 2001 . Motion verbs with goal PPs in the L2 acquisition of English and Japanese. Studies in Second Language Acquisition, vol. 23, pp. 153-170.

INAGAKI, S., 2002. Japanese learners' acquisition of English manner-of-motion verbs with locational/directional PPs. Second Language Research, vol. 18, pp. 3-27.

JU, M., 2000. Overpassivization errors by second language learners: The effects of conceptualizable agents in discourse. Studies in Second Language Acquisition, vol. 22, pp. 85111.

JUFFS, A., 1996. Learnability and the lexicon. Amsterdam: Benjamins.

KONDO, T., 2003. Overpassivisation in second language English: Morphological influence on the acquisition of unaccusative verbs. Retrieved at: www.englisharticles.294/org.

KONDO, T., 2005. Overpassivization in second language acquisition. IRAL, vol. 43, pp. 129161.

MANSOORI, M., 2005. Sakhte sabbabi zaban farsi bar asas tarh pooste feli (Accusative structure in the Persian language based on light verb framework). Zaban va Zabanshenasi, no. 1, pp. 91-114.

MONTRUL, S., 1999. Causative errors with unaccusative verbs in L2 Spanish. Second Language Research, vol. 15, no. 2, pp. 191-219.

MONTRUL, S., 2000. Transitivity alternations in L2 acquisition: Toward a modular view of transfer. Studies in Second Language Acquisition, no. 2, pp. 229-273.

MONTRUL, S., 2001 a. Causatives and transitivity in L2 English. Language Learning, vol. 51, no. 1, pp. 51-106.

MONTRUL, S., $2001 \mathrm{~b}$. Agentive verbs of manner of motion in Spanish and English as second languages. Studies in Second Language Acquisition, vol. 23, pp. 171-206.

MONTRUL, S., 2004. Psycholinguistic evidence for split intransitivity in Spanish second language acquisition. Applied Psycholinguistics, vol. 25, no. 2, pp. 239-267.

OSHITA, H., 2001. The unaccusative trap in second language acquisition.

Studies in Second Language Acquisition, vol. 23, pp. 279-304.

PINKER, S., 1989. Learnability and cognition: The acquisition of argument structure. Cambridge, MA: MIT Press. 
SAVILLE-TROIKE, M., 2005. Introducing second language acquisition. Cambridge: Cambridge University Press.

SCHWARTZ, B., and SPROUSE, R., 1996. L2 cognitive states and the Full Transfer/Full Access model. Second Language Research, vol. 12, pp. 40-72.

SORACE, A. and SHOMURA, Y., 2001. Lexical constraints on the acquisition of split intransitivity: Evidence from L2 Japanese. Studies in second language acquisition, vol. 23, no. 2, pp. 247-278.

WHITE, L., 2003. Second language acquisition and universal grammar. Cambridge: Cambridge University Press.

WHITE, L., MONTRUL, S., HIRAKAWA, M., CHEN, D., BRUHN DE GARAVITO, J. and BROWN, C., 1998. Zero morphology and the T/SM restriction in the $L 2$ acquisition of psych verbs. In: $L$. $M$. Beck, ed. Morphology and the interface in L2 knowledge Amsterdam: Benjamins, pp. 257282.

WHONG-BARR, M., 2005. Transfer of argument structure and morphology. In: Dekydtspotter et al., eds. Proceedings of the 7th Generative Approaches to Second Language Acquisition Conference (GASLA 2004). Somerville, MA: Cascadilla Proceedings Project.

YIP, V., 1990. Interlanguage ergative constructions and learnability. CUHK Papers in Linguistics, no. 2, pp. 45-68.

YUAN, B., 1999. Acquiring the unaccusative/unergative distinction in a second language: Evidence from English-speaking learners of Chinese. Linguistics, vol. 37, pp. 275-296.

ZOBL, H., 1989. Canonical typological structure and ergativity in English L2 acquisition. In: S. Gass and J. Schachter, eds. Linguistic perspectives on second language acquisition. New York: Cambridge University Press, pp. 203-221.

\section{Appendix: The forced-choice elicitation test}

1. Last month, there was a strong earthquake in this area. Many houses (damaged/were damaged) in the earthquake and the tsunami that followed it.

2. There was a very big circus in our town last week. A magician was there who (appeared a rabbit/made a rabbit appear) out of a hat.

3. Yesterday, I took my five year old daughter to the zoo. At first, she liked everything, but she (cried/was cried) seeing some birds in their cage. She wanted to take them home.

4. Some people believe that some gases existing in the inner layers of the earth (make the earthquakes happen/happen the earthquakes).

5. The boys started to throw stones at the train as it was passing. Suddenly, one of the windows of the train (broke/was broken), which frightened the passengers greatly.

6. John wanted to teach swimming to his five year old brother. They went to the shallow parts of the river. John (swam the child/made the child swim).

7. I saw a movie last night. The main character was a man who (disappeared/was disappeared) by drinking a magic liquid whenever he wanted.

8. Yesterday, a robbery (occurred/was occurred) in the bank near our house. The robbers stole a lot of money and ran away.

9. Today, I didn't have time to make lunch. There was some soup from last night in the fridge. I heated it but the colour of the soup (changed/was changed) slowly.

10. Yesterday, a bad storm happened in my town. It was so strong that many trees (broke/were broken). There was no electricity for some hours too.

11. There is a great shopping mall in our city, which has many automatic doors. The doors (open/are opened) as you stand in front of them.

12. As a result of the sea storm last night, many boats (sank/were sunk) in the water near the sea shore.

13. I was driving with my old car this morning. Suddenly, the engine (died/was died) and the car stopped in the middle of the road.

14. I had some guests yesterday. I had a lot of work to do including preparing food for them. Luckily, all the food (had cooked/had been cooked) before they came.

15. After several days of raining, the sun (emerged/was emerged) from behind the clouds today.

16. I hit the library in my living room. Several books (fell/ were fallen) on the ground.

17. There was a great earthquake in the southeast of Asia last week. The ground (cracked/was cracked). There were also very big waves in the sea. 
18. Literature students of this university need to study many literary works of great writers. Many stories and novels (read/are read) in their classes.

19. This morning, while I was coming out of the kitchen with a glass of water in my hand, I slipped and the water (spilled/was spilled) all over the carpet.

20. After the big flood in the north cities of the country, many houses (built/were built) by the government for people who became homeless.

21 . In some parts of the country, the temperature is very high during the day. All flowers and plants (wither/are withered) in such heat.

22. As I was looking out of the window, I saw a man standing under the rain, but a minute later, he (vanished/was vanished).

23. After several hours of questioning, the men arrested by the police (released/ were released) from jail.

24. With the introduction of computers, huge amounts of information (stored/were stored) on small discs.

25. All the police and some people were looking for the missing child. Finally, he (found/was found) in the jungle.

26. The research budget of the company (rose/was risen) by the new board of the directors.

27. When she was four years old, Mary (abandoned/was abandoned) by her father. She lived with her mother and grandmother.

28. Because of the drought, the government asked the farmers in the region not to plant rice. New crops (planted/were planted) instead.

29. The members of the committee agreed on new decisions. New policies (determined/were determined) to increase the quality of the products.

30. The bad storm caused many damages in the harbour last night. The sails of some boats (ripped/were ripped) under the force of the wind.

31. I put some chocolate on my table. Because it was hot inside the room, it (melted/was melted) slowly.

32. The man in the black suit behaved very strangely. When a policeman started to look him, he bent down so he (didn't see/wasn't seen).

33. The facilities in that hotel were very good. Its stuff provided whatever that (needed/was needed).

34. He is lucky because at least he has a house where he could (sleep/be slept).

35 . He is a trainer of race horses. In order to prepare them for the race, he (runs them/makes them run) long distances.

36. Sam is very good in taking care of small children. He tells them funny stories and (laughs them/makes them laugh).

37. The sad story of the movie had a bad effect on Sara. It (cried her/made her cry) for a long time.

38. Last night, there was a heavy snow. A lot of snow (sat/ was sat) on the roof of the house. 39. The big vase (stood/ was stood) in the corner of the room near the fireplace.

40. The custom of providing a bride with some house wares still (exists/is existed) in some parts of the world.

41. The passenger asked the policeman in the station if he knew when the next flight to New York (departed/was departed).

42. The man was so fat that the chair (collapsed/was collapsed) under his weight.

43. Last night the sky was clear and cloudless. A beautiful moon (shone/was shone) brightly in the sky.

44. John and his friends went to the jungle last Friday. Suddenly, it started to rain heavily. They (stayed/were stayed) in a cottage until the rain stopped.

45. Sara is a very pleasant friend. She is very easy to (talk/ be talked) to.

46. I went to the woods yesterday. It was a beautiful day. The birds (sang/were sung) on top of the trees.

47. The workers could not reach an agreement with the factory owners. As a result, the strike (continued/was continued) for several more days.

48. In autumn, the scene of the yellow and green leaves on the lake is very beautiful. It seems that they (are dancing/ are being danced) on the water. 
Author's address and contact details Professor Farzaneh Dehghan

Department of English Language Teaching

Farhangian University

Shiraz

Iran

E-mail: fdehghan175@gmail.com

Professor Reza Rezvani

English Department

Yasouj University

Kohgiluye \& BoyerAhmad

Iran

E-mail: rezvanireza@gmail.com 